\title{
IMPACT OF NON-SMOKING ORDINANCES
} ON HOSPITALITY REVENUES:

\section{THE CASE OF GERMANY}


Hamburg Contemporary Economic Discussions

University of Hamburg

Faculty Economics and Social Science

Chair for Economic Policy

Von-Melle-Park 5

D-20146 Hamburg | Germany

Tel $+494042838-4622$

$\mathrm{Fax}+494042838-6251$

http://www.uni-hamburg.de/economicpolicy/

Editor: Wolfgang Maennig

P. Gabriel M. Ahlfeldt

University of Hamburg

Faculty Economics and Social Science

Chair for Economic Policy

Von-Melle-Park 5

D-20146 Hamburg | Germany

Tel $+494042838-5569$

Fax $+494042838-6251$

ahlfeldt@econ.uni-hamburg.de

Wolfgang Maennig

University of Hamburg

Faculty Economics and Social Science

Chair for Economic Policy

Von-Melle-Park 5

D-20146 Hamburg | Germany

Tel $+494042838-4622$

Fax $+494042838-6251$

maennig@econ.uni-hamburg.de

ISSN 1865 - 2441 (Print)

ISSN 1865 - 7133 (Online)

ISBN 978 - 3 - 940369 - 66 - 6 (Print)

ISBN $978-3-940369-67-3$ (Online) 
Gabriel M. Ahlfeldt \& Wolfgang Maennig

\title{
Impact of Non-smoking Ordinances on Hospitality Revenues: The Case of Germany*
}

\begin{abstract}
Non-smoking ordinances are among the most popular albeit controversial public health-care legislations worldwide. This article provides an empirical assessment of the impact of non-smoking ordinances on bar and restaurant revenues in German Federal States. By application of panel spline regression and difference-in-difference strategies, we find negative impact limited to bars in the very short run. If any, there is a positive impact on total expenditures in the long run, indicating that either consumption pattern has not changed at all or that any reduction in spending by smokers is compensated for by a corresponding increase by non-smokers. These findings support the German - and similar - non-smoking legislations in the sense that positive externalities resulting from reduced health care cost are likely to outweigh the risk to businesses in the hospitality sector, at least in the long run. Keywords: Bar Revenues, Non-smoking Ordinances, Restaurant Revenues

JEL classification: 118, K32
\end{abstract}

Version: June 2009

\section{Introduction}

Non-smoking ordinances for public spaces in general and bars and restaurants in particular are among the most frequently applied and controversially discussed public health initiatives worldwide. The rationale on which these ordinances has been built is straightforward - they aim at reducing the exposure of non-smokers to secondhand smoke and, hence, their susceptibility to respiratory and heart diseases, and ultimately a reduction in health care costs. This argument applies to bar and restaurant visitors and particularly to employees, who might be less free in choice than customers or patrons. Furthermore, the empirical literature suggests smoking bans to reduce the overall consumption of tobacco products (PAK$\mathrm{KO}, 2006)$, which cause significant social costs estimated at $0.1 \%-1.1 \%$ of GDP (LIGHTWOOD et al., 2000). In contrast to increasing taxation of tobacco products,

\footnotetext{
* We thank Johannes Rothmaler for excellent research assistance.
} 
the impact of smoking bans cannot be neutralized by an increase in smuggling of tobacco products. In terms of traditional welfare economics, this argument is sometimes questioned since, in principle, and given the respective demand from non-smokers, markets should be able to provide smoke-free spaces in bars and restaurants without the intervention of the state. Critics of non-smoking ordinances argue that undesirable loss of choice will result in reduced bar and restaurant revenues. This criticism implies the assumption that the decrease in expenditure of smokers would be greater than the increase in expenditure of nonsmokers. However, this is a purely empirical issue and can hardly be affirmed on the basis of existing empirical evidence concentrated on the U.S. ${ }^{1}$ To our knowledge, this study is the first multivariate empirical analysis of economic impact of a non-smoking ordinance in Europe.

We extend the literature on the impact of (non-)smoking ordinances on bar and restaurant revenues by providing new evidence based on the German smoke-free bar and restaurant ordinance implemented by the 16 German Federal States between autumn 2007 and the beginning of 2008. Using a spline regression panel approach, we distinguish between short-run and long-run impact, which may run in opposite directions. We exploit the fact that the new legislation was introduced by states at different dates as a key feature of our analysis. This particularity facilitates the first application of a quasi-experimental difference-indifference (DD) strategy in the realm of smoking ban literature, allowing for more efficient control for macroeconomic conditions compared to previous studies.

\section{Background}

\subsection{Literature Survey}

The economic impact of non-smoking ordinances on the gastronomy, mainly in the U.S., has been investigated on the basis of survey data (ADDA, BERLINSKI, \& MACHIN, 2007; DUNHAM \& MARLOW, 2000, 2003) as well as official statistics.

\footnotetext{
See e.g. COWLING \& BOND (2005) and PARKER \& CHANG (2007); for evidence from outside the
} U.S., see BLECHER (2006), EDWARDS et. al. (2008) and EVANS (2005). 
Although some of the latter employ ARIMA-models (e.g. STOLZENBERG \& D'ALESSIO, 2007), the literature is dominated by analyses based on multivariate regressions. These studies have frequently made use of employment data (ADAMS \& COTTI, 2007; ALPERT et al., 2007; THOMPSON et al., 2008). Less common indicators include purchasing prices of restaurants (ALAMAR \& GLANTZ, 2004) tourism demand (GLANTZ \& CHARLESWORTH, 1999) or non-economic indicators like air quality (ALPERT et al., 2007). SCOLLO \& LAL (2008) provide an extensive survey on these strands of research.

In this analysis we make use bar and restaurant revenues, which have also been frequently employed in the literature. Only few of the newer studies, however, reveal a significantly negative impact of non-smoking ordinance on bar and restaurant revenues, ${ }^{2}$ among these PAKKO (2007) and COWLING \& BOND (2005) for California (USA) and EVANS (2005) for Canada. Some studies instead provide evidence for (weakly) positive impacts, e.g. BLECHER (2006) for South-Africa, DAl et al. (2004) for Florida (USA), EDWARDS et al. (2008) for New-Zeeland or PARKER \& CHIANG (2007) for California (USA) while others do not find any significant impact at all (e.g. ALPERT et al., 2007).

\subsection{Non-Smoking Ordinances in German Federal States}

After the voluntary agreement to improve the non-smoking protection for guests and employees in the hospitality industry between the German Hotel and Restaurant Association and the German Federal Ministry of Health and Social Security, dated 1 March 2005 (BUNDESMINISTERIUM FÜR GESUNDHEIT UND SOZIALE SICHERUNG/DEUTSCHER HOTEL UND GASTSTÄTTENVERBAND, 2005), failed in spring 2007 (BUNDESMINISTERIUM FÜR GESUNDHEIT, 2007), Germany implemented statutory smoking bans for the first time in autumn 2007. The first smoking bans entered into force in the federal states of Baden-Württemberg and Lower Saxony on 1 August 2007 and in Hesse on 1 October 2007. With the excep-

Studies on the impact on bar and restaurant revenues that were published before 2000 , include GLANTZ \& SMITH $(1994,1997)$ and SCIACCA \& RATLIFF (1998), among others. 
tion of the states North-Rhine Westphalia, Rhineland Palatinate, Saarland, Saxony and Thuringia, where smoking bans became effective only in February 2008, or July 2008 in the case of Thuringia, the remaining states implemented their smoking bans as of 1 January 2008.

Non-smoking laws primarily impose a smoking ban on restaurants, but do allow for the set-up of separate "smoking rooms". Only Bavaria banned smoking from restaurants without any exceptions whatsoever. In Saarland, and in Saxony since 1 March 2008, smoking is permitted not only in smoking rooms, but also in owner-operated restaurants without employees. Discothèques, defined as restaurants (Gaststätten) under section 1 of the German Restaurants Act (GastG), are also subject to the smoking ban. In the states Baden-Württemberg, Brandenburg, Saxony and Saxony-Anhalt, however, smoking rooms are not permitted. Bavaria's smoking ban in this context does not allow for any exceptions. Party tents or marquees are exempt from the smoking ban in some states.

In its decision on 30 July 2008, Germany's Federal Constitutional Court (BVerfG) found, regarding constitutional challenges brought against the smoking bans in Baden-Württemberg and Berlin by operators of restaurants and discothèques, that the state regulations violated the complainants' fundamental right to pursue a trade under Art. 12 I GG (German Basic Law). Furthermore, the court found that it violated the principle of equality under Art. 3 GG if licensed smoking rooms in restaurants were banned from discothèques (cf. BVerfG, 1 BvR 3262/07 dated 30 July 2008).

However, the decision did not void these regulations. Instead, they continue to remain in force until a constitutional revision of the regulations - which must be completed by 31 December 2009-with the proviso that restaurants shall be exempted that do not have smoking rooms; that do not serve prepared food; that have a guest area of less than 75 sq. m.; that do not admit persons under the age of 18; and that are classified as a "smoking restaurant". In addition, smoking rooms shall be permitted in discothèques if such rooms are also permitted in restaurants (cf. BVerfG, 1 BVR 3262/07 dated 30 July 2008, para. 161 ff.). 
Even though the decision referred only to the regulations in the states of BadenWürttemberg and Berlin, almost all other states have since applied the corresponding laws subject to the conditions set by the Federal Constitutional Court. One exception is Rhineland-Palatinate, where similar modifications have been in force since the smoking ban came into effect on 15 February 2008 (cf. Administrative Court [VGH] decision VGH Rhineland-Palatinate, VGH A 32/07, etc. dated 11 August 2008, as well as the decision VGH Rhineland-Palatinate, VGH B 31/07, etc. dated 30 September 2008). In Saxony-Anhalt, however, the conditions set by the Federal Constitutional Court have been applied only since the end of October 2008 (cf. decision of State Administrative Court [LGV] of Saxony-Anhalt, LVG 3/08, etc. dated 22 October 2008). In Bavaria, the smoking ban remains in effect without any exceptions, which is to be considered constitutional according to the reasoning of the Federal Constitutional Court (cf. BVerfG, 1 BvR 3162/07 dated 30 July 2008, para. 121: "On the basis of the latitude that must be afforded the legislator, it would not be prevented [...] from imposing a strict smoking ban in restaurants."). In Saarland, the Protection of Non-Smokers Act continues to apply unchanged, which provides for exceptions for micro-enterprises and also allows for smoking rooms in discothèques. The respective state regulations are shown in Table A1 (see appendix).

\section{Empirical Analyses}

Throughout our empirical analyses we investigate the evolution of per capita revenues $\left(R P C_{i t}\right)$ in the hospitality sector at the levels of months $(t)$ and German Federal States (i). Besides total revenues, revenues of bars (including discos und dancing halls) and restaurants (including cafes, ice cream parlors and snack bars) are considered individually. Data are retrieved from the monthly survey in the hospitality sector conducted by the German Federal Statistical Office (Monatserhebung im Gastgewerbe). The survey is based on a random sample of businesses with annual revenues exceeding $€ 50,000$, covering $8 \%$ of all businesses (STATISTISCHES BUNDESAMT, 2008a, p. 6). Data are analyzed within a panel framework that allows for unobserved time-invariant effects $\left(f_{i}\right)$. Our empirical specifications test 
for a significant percentage impact on the revenues of the smoking ban legislation. As a control for macroeconomic conditions, which affect income levels and willingness to spend money in bars or restaurants, we add the rate of unemployment $\left(\right.$ unemp $\left._{\text {it }}\right)$. Potential seasonality is accounted for by a set of quarterly dummy variables $\left(S D_{t}\right)$. Our final specification, allowing for level shifts as well as a linear spline, reads as follows:

$$
\begin{aligned}
\log \left(R P C_{i t}\right)= & \alpha+S D_{t} a+\beta \text { unemp }_{i t} \\
& +\gamma_{1} \text { ban }_{i t}+\gamma_{2} \text { ban }_{i t} \times \text { strend }_{i t}+\text { trend }_{t}+f_{i}+\varepsilon_{i t}
\end{aligned}
$$

where $b a n_{i t}$ is a dummy variable indicating whenever a smoking ban was in operation in state $i$; trend ${ }_{t}$ is a quarterly trend variable starting at the beginning of our observation period; and strend $_{i t}$ is a trend variable similar to trend that starts at the time the smoking ban was put into operation in state $i{ }^{3}$ Parameters $a, \alpha$, and $\beta$ as well as $\gamma_{1}$ and $\gamma_{2}$ are the coefficients to be estimated while $\varepsilon_{i t}$ is a random error term component. Serial autorcorrelation, which we detected using the Lagrange multiplier (LM) test for serial correlation in a fixed effects model (BALTAGI, 2001, pp. 94-95) ${ }^{4}$ is addressed by clustering standard errors at the state level (BERTRAND, DUFLO, \& MULLAINATHAN, 2004). In the present specification, the percentage impact on revenues in the first month of a smoking ban being in operation can be inferred from coefficient $\gamma_{1}{ }^{5}$ In contrast, $V_{2}$ is the percentage change in revenues after the first month of operation, conditional on other factors, and can indicate either an effect of recovery, amplification or persistency. A number of alterations to specification (1) are tested using either per capita revenues of the total hospitality sector (Table 1 ) or per capita revenues of bars (Table 2) and restaurants (Table 3 ) as an endogenous variable.

See GREENE (2003, pp. 121-122) and MARSH \& CORMIER (2001), among others, for background on how to set up spline regression models.

4 The $L M$ test statistic is $L M_{5}=\sqrt{N T^{2} /(T-1)\left(\tilde{v}^{\prime} \tilde{v}_{-1} / \tilde{v}^{\prime}\right.} \tilde{v}$; asymptotically distributed as $N(0,1)$.

5 According to the standard interpretation of a semi-log model, the percentage impact corresponds to $\exp (b-1) \times 100$, where $b$ is the estimated coefficient value (HALVORSEN \& PALMQUIST, 1980). 
At the first stage of the empirical analysis we consider a reduced model specification where the interactive term ban $_{i t} \times$ strend $_{i t}$ is omitted. This specification provides a test for a significant shift in average per capita revenues between the periods prior to and after implementation of the smoking ban (columns 1). No significant impact on revenues is evident from the results. Therefore, we modify the column (1) specification to facilitate separate estimates on short-run (at three months) and long-run impact (after three months) (columns 2). Similarly, in columns (3) we distinguish between periods when a rigid or more attenuated (non-)smoking legislation was in operation, following the decision of the Federal Constitutional Court (BVerfG). On the basis of the coefficient estimates on the dummy variables sban $_{i t}$ (short-run effect), Iban $_{i t}$ (longrun effect), rban $_{i t}$ (rigid ban) and wban $_{i t}$ (weak ban) displayed in columns (2) and (3), we cannot reject that the smoking ban had no impact on the per capita consumption in the hospitality sector. If any, there are signs of a small increase in per capita bar revenues of about $3.8 \%$ three months after smoking ban implementation, indicated by the weakly significant coefficient on $\mathbf{I b a n}_{i t}$ in Table 2. No significant effects are found for restaurant revenues.

It might be argued that consumer behavior changes gradually since expectation of the benefit from going out are not adjusted for immediately. In the next step, we therefore turn our attention to whether there is evidence for a significant impact on trends in revenues. Building on specification (1) and omitting $b a n_{i t}$, the column (4) specification tests for a linear spline occurring in the evolution of per capita revenues after implementation of the new legislation. Empirical results, again, do not allow rejection of the hypothesis of no impact on revenues. Finally, we estimate specification (1) which allows both for a level shift that accounts for an immediate reaction as well as a trend impact capturing gradual adjustment processes. Potentially, this specification may isolate opposing short- and long-run influences, i.e. a negative impact in the short-run, accompanied by a subsequent recovery effect. Indeed, we find a significantly positive impact on total per capita revenues of $0.5 \%$ per month while the coefficient on the short-run intercept $\left(b a n_{i t}\right)$ is not statistically significant at conventional levels. For restaurants and 
bars individually, no significant impact can be asserted, even on the basis of this quite flexible specification.

Notably, a significant downward trend is found in per capita consumption, accompanied by the expected negative impact of the rate of unemployment. Seasonality effects are similarly in line with expectations, pointing to significantly reduced (increased) per capita revenues in the winter (summer) months of roughly $10 \%$ (Table 1 ). While these results are similarly obtained for restaurant revenues (Table 3), per capita bar revenues are less influenced by long-run trend, macroeconomic conditions and the summer spending effect.

Tab. 1 Impact on Per Capita Bar and Restaurant Revenues

\begin{tabular}{|c|c|c|c|c|c|}
\hline & (1) & $(2)$ & (3) & (4) & $(5)$ \\
\hline \multirow[t]{2}{*}{ trend } & $-0.0097 * *$ & $-0.0100 * *$ & $-0.0100 * *$ & $-0.0107 * *$ & $-0.0104 * *$ \\
\hline & $(0.0043)$ & $(0.0044)$ & $(0.0043)$ & $(0.0044)$ & $(0.0045)$ \\
\hline \multirow{2}{*}{$S D_{\text {(Jan-March) }}$} & $-0.0936 * * *$ & $-0.0912 * *$ & $-0.0935 * * *$ & $-0.0922 * *$ & $-0.0895 * *$ \\
\hline & (0.0309) & $(0.0317)$ & $(0.0311)$ & $(0.0318)$ & (0.0319) \\
\hline \multirow[t]{2}{*}{$S D_{\text {(April-June) }}$} & $0.0721 * *$ & $0.0704 * *$ & $0.0722 * *$ & $0.0695^{* *}$ & $0.0707 * *$ \\
\hline & (0.0310) & (0.0299) & $(0.0312)$ & $(0.0303)$ & $(0.0306)$ \\
\hline \multirow{2}{*}{$S D_{(J u y-\text { Sept) }}$} & $0.115^{* *}$ & $0.114 * *$ & $0.115^{* *}$ & $0.110 * *$ & $0.110 * *$ \\
\hline & $(0.0488)$ & $(0.0478)$ & $(0.0483)$ & $(0.0473)$ & 0.0474 \\
\hline \multirow[t]{2}{*}{ unemp } & $-0.0676 * *$ & $-0.0688^{* *}$ & $-0.0677 * *$ & $-0.0709 * *$ & $-0.0706 * *$ \\
\hline & $(0.0266)$ & $(0.0267)$ & $(0.0267)$ & $(0.027)$ & $(0.0272)$ \\
\hline \multirow[t]{2}{*}{ ban } & 0.0083 & & & & -0.0173 \\
\hline & (0.0132) & & & & $(0.0114)$ \\
\hline \multirow[t]{2}{*}{ sban } & & -0.0024 & & & \\
\hline & & $(0.0142)$ & & & \\
\hline \multirow[t]{2}{*}{ Iban } & & 0.0177 & & & \\
\hline & & (0.0192) & & & \\
\hline \multirow[t]{2}{*}{ rban } & & & 0.0078 & & \\
\hline & & & $(0.0133)$ & & \\
\hline \multirow[t]{2}{*}{ wban } & & & 0.0125 & & \\
\hline & & & (0.0199) & & \\
\hline \multirow[t]{2}{*}{ ban $\times$ strend } & & & & 0.0040 & $0.0055 * *$ \\
\hline & & & & (0.0024) & $(0.0023)$ \\
\hline Obs. & 528 & 528 & 528 & 528 & 528 \\
\hline $\mathrm{R}^{2}$ (within) & 0.547 & 0.548 & 0.547 & 0.549 & 0.55 \\
\hline
\end{tabular}

Notes: The endogenous variable is the log of the per capita bar and restaurant revenues in all models. All models include state (Bundesländer) effects. Standard errors are robust for heteroscedasticity and clustered at the state (Bundesländer) level. ${ }^{*},{ }^{* *}$ and ${ }^{* * *}$ denote significance at the 10,5 , and 1 percent levels, respectively. 
Tab. 2 Impact on Per Capita Bar Revenues

\begin{tabular}{|c|c|c|c|c|c|}
\hline & $(1)$ & $(2)$ & (3) & (4) & (5) \\
\hline \multirow[t]{2}{*}{ trend } & -0.0047 & $-0.0053^{*}$ & -0.0048 & -0.0050 & -0.0051 \\
\hline & $(0.0030)$ & $(0.0029)$ & $(0.0030)$ & $(0.0032)$ & $(0.0032)$ \\
\hline \multirow[t]{2}{*}{$S D_{\text {(Jan-March) }}$} & $-0.154 * * *$ & $-0.149 * * *$ & $-0.153 * * *$ & $-0.150 * * *$ & $-0.152 * * *$ \\
\hline & $(0.0295)$ & $(0.0284)$ & $(0.0296)$ & $(0.0306)$ & (0.0299) \\
\hline \multirow[t]{2}{*}{$S D_{\text {(April-June) }}$} & $-0.0477^{*}$ & $-0.0509 *$ & $-0.0471^{*}$ & $-0.0479 *$ & $-0.0484 *$ \\
\hline & $(0.0243)$ & $(0.0243)$ & $(0.0242)$ & $(0.0241)$ & $(0.0243)$ \\
\hline \multirow{2}{*}{$S D_{(J u l y-S e p t)}$} & -0.028 & -0.0313 & -0.0305 & -0.0311 & -0.0309 \\
\hline & $(0.0341)$ & (0.0339) & $(0.0346)$ & $(0.0347)$ & $(0.0346)$ \\
\hline \multirow[t]{2}{*}{ unemp } & -0.00693 & -0.00908 & -0.00721 & -0.00824 & -0.00838 \\
\hline & $(0.0205)$ & (0.0197) & $(0.0205)$ & $(0.0212)$ & $(0.0211)$ \\
\hline \multirow[t]{2}{*}{ ban } & 0.0205 & & & & 0.00785 \\
\hline & $(0.0192)$ & & & & $(0.0227)$ \\
\hline \multirow[t]{2}{*}{ sban } & & 0.0007 & & & \\
\hline & & $(0.0232)$ & & & \\
\hline \multirow[t]{2}{*}{ Iban } & & $0.0383 *$ & & & \\
\hline & & (0.0206) & & & \\
\hline \multirow[t]{2}{*}{ rban } & & & 0.0184 & & \\
\hline & & & $(0.0192)$ & & \\
\hline \multirow[t]{2}{*}{ wban } & & & 0.0387 & & \\
\hline & & & $(0.0311)$ & & \\
\hline \multirow[t]{2}{*}{ ban $\times$ strend } & & & & 0.0035 & 0.0027 \\
\hline & & & & $(0.0028)$ & $(0.0034)$ \\
\hline Obs. & 528 & 528 & 528 & 528 & 528 \\
\hline$R^{2}$ (within) & 0.22 & 0.225 & 0.221 & 0.221 & 0.221 \\
\hline
\end{tabular}

Notes: The endogenous variable is the log of the per capita bar revenues in all models. All models include state (Bundesländer) effects. Standard errors are robust for heteroscedasticity and clustered at the state (Bundesländer) level. ${ }^{*},{ }^{* *}$ and ${ }^{* * *}$ denote significance at the 10,5 , and 1 percent levels, respectively. 
Tab. 3 Impact on Per capita Restaurant Revenues

\begin{tabular}{|c|c|c|c|c|c|}
\hline & (1) & (2) & (3) & (4) & (5) \\
\hline \multirow[t]{2}{*}{ trend } & $-0.0066 * *$ & $-0.0065 *$ & $-0.0065^{* *}$ & $-0.0072^{* *}$ & $-0.0070^{* *}$ \\
\hline & $(0.0030)$ & $(0.0031)$ & $(0.0030)$ & $(0.0030)$ & $(0.0030)$ \\
\hline \multirow{2}{*}{$S D_{\text {(Jan-March) }}$} & $-0.115^{* * *}$ & $-0.115^{* * *}$ & $-0.115^{* * *}$ & $-0.114^{* * *}$ & $-0.112 * * *$ \\
\hline & $(0.0242)$ & $(0.0246)$ & $(0.0243)$ & $(0.0247)$ & $(0.0246)$ \\
\hline \multirow{2}{*}{$S D_{\text {(April-Une) }}$} & 0.0331 & 0.0335 & 0.0326 & 0.0315 & 0.0324 \\
\hline & $(0.0236)$ & $(0.0231)$ & $(0.0238)$ & (0.0233) & $(0.0233)$ \\
\hline \multirow{2}{*}{$S D_{(\text {(ull-sept) }}$} & $0.0753^{*}$ & $0.0757 * *$ & $0.0773 * *$ & $0.0723 *$ & $0.0719^{*}$ \\
\hline & $(0.0358)$ & $(0.0353)$ & $(0.0358)$ & $(0.0350)$ & $(0.0351)$ \\
\hline \multirow[t]{2}{*}{ unemp } & $-0.0395^{* *}$ & $-0.0392 *$ & $-0.0393 *$ & $-0.0414 * *$ & $-0.0412^{* *}$ \\
\hline & $(0.0184)$ & $(0.0187)$ & $(0.0186)$ & $(0.0185)$ & $(0.0186)$ \\
\hline \multirow[t]{2}{*}{ ban } & 0.0031 & & & & -0.0115 \\
\hline & $(0.0086)$ & & & & $(0.0124)$ \\
\hline \multirow[t]{2}{*}{ sban } & & 0.0056 & & & \\
\hline & & $(0.0112)$ & & & \\
\hline \multirow[t]{2}{*}{ Iban } & & 0.00083 & & & \\
\hline & & (0.0129) & & & \\
\hline \multirow[t]{2}{*}{ rban } & & & 0.0048 & & \\
\hline & & & (0.0089) & & \\
\hline \multirow[t]{2}{*}{ wban } & & & -0.0112 & & \\
\hline & & & (0.0135) & & \\
\hline \multirow[t]{2}{*}{ ban $\times$ strend } & & & & 0.0021 & 0.0031 \\
\hline & & & & (0.0019) & $(0.0025)$ \\
\hline Obs. & 528 & 528 & 528 & 528 & 528 \\
\hline $\mathrm{R}^{2}$ (within) & 0.526 & 0.526 & 0.526 & 0.527 & 0.527 \\
\hline
\end{tabular}

Notes: The endogenous variable is the log of the per capita restaurant revenues in all models. All models include state (Bundesländer) effects. Standard errors are robust for heteroscedasticity and clustered at the state (Bundesländer) level. ${ }^{*},{ }^{* *}$ and ${ }^{* * *}$ denote significance at the 10, 5, and 1 percent levels, respectively.

The federal states did not put into operation smoking bans at the same time. Smoking bans started as early as August 2007 in the states of BadenWuerttemberg and Lower Saxony. Hesse followed two months later in October 2007. We can, therefore, explicitly exploit the period prior to January $1^{\text {st }}, 2008-$ when smoking bans were also implemented in most of the other states, to assess how revenues changed in reaction to smoking ban legislation in comparison to states where no similar intervention occurred. The unaffected states may serve as a control group in a quasi-experimental research strategy. We use simple DD specification to estimate our coefficients of interest, i.e. $\gamma_{1}$ and $\gamma_{2}$. The DD specification is derived from specification (1) by taking differences and substituting the macroeconomic controls (quarterly dummies and $u n e m p_{i t}$ ) by a full set of monthly 
time effects $d_{t^{\circ}}{ }^{6}$ Coefficients $\gamma_{1}$ and $\gamma_{2}$ in equation (2) provide DD estimates in the sense that they differentiate the evolution of per capita revenues both between groups (affected and not-affected by smoking legislation) and time (prior to and after the intervention). Besides adjusting flexibly to macroeconomic conditions, this specification features the possibility of allowing the intervention to occur at different points in time within different states. Since after 1 January 2008, smoking bans were in operation in all states we omit this period from the sample in the respective estimates. Compared to specification (1), the DD estimator is more promising in identifying short-run impacts, due to better macroeconomic control, while the reduced post intervention period complicates inference on long-run trend impacts.

$$
\begin{aligned}
\log \left(R P C_{i t}\right)-\log \left(R P C_{i t-1}\right)=\alpha+d_{t}+\gamma_{1}\left(\operatorname{ban}_{i t}-\text { ban }_{i t-1}\right) \\
\quad+\gamma_{2}\left(\text { ban }_{i t} \times \text { strend }_{i t}-\text { ban }_{i t-1} \times \text { strend }_{i t-1}\right)+\varepsilon_{i t}-\varepsilon_{i t-1}
\end{aligned}
$$

Results corresponding to equation (2) are presented in Table 4 for total revenues (columns 1 and 4) as well as revenues of bars (columns 2 and 5) and restaurants (columns 3 and 6). All but coefficient $\gamma_{1}$ in the case of bar revenues remain statistically insignificant at conventional levels.

As shown by FLECK \& HANSSEN (2008), it is crucial to control appropriately for trends in order to precisely assess the intervention effect of smoking bans to avoid spurious evidence. Since there is the possibility of trends not being homogenous across states, we re-estimate equation (2) in a (state) fixed effects model, which in time-difference form captures trend effects at the state level (Table 4, columns 3-6). Results, however, remain almost unchanged, again pointing to a significantly negative impact on per capita consumption in bars of approximately $6 \%$. Since the respective coefficients on $V_{2}$ are insignificant, we cannot reject persistency of the effect during the months following the implementation of the smoking ban. We note that our estimated short-run

6 Similar DD specifications that regress the growth rate of the endogenous variable on a full set of time effects and interaction dummies have recently been employed by AHLFELDT \& MAENNIG (2009) and REDDING \& STURM (2008). 
treatment effect points to an almost twice as high reduction of bar revenues compared to the effects revealed by descriptive evidence in an analysis by the German Statistical office (STATISTISCHES BUNDESAMT, 2008b). ${ }^{7}$

Tab. 4 Difference-in-Difference Estimates

\begin{tabular}{lcccccc}
\hline \hline & $\begin{array}{c}(1) \\
\text { (bars \& } \\
\text { restaurants) }\end{array}$ & $\begin{array}{c}(2) \\
\text { (bars) }\end{array}$ & $\begin{array}{c}(3) \\
\text { (restaurants) }\end{array}$ & $\begin{array}{c}(4) \\
\text { (bars \& } \\
\text { restaurants) }\end{array}$ & $\begin{array}{c}\text { (5) } \\
\text { (bars) }\end{array}$ & $\begin{array}{c}(6) \\
\text { (restaurants) }\end{array}$ \\
\hline ban & -0.0314 & $-0.0596^{* *}$ & -0.0169 & -0.0306 & $-0.0602 * *$ & -0.0162 \\
Sbanxtrend & $(0.0422)$ & $(0.0214)$ & $(0.0236)$ & $(0.0427)$ & $(0.0213)$ & $(0.0241)$ \\
& 0.00472 & 0.0179 & -0.0023 & 0.0059 & 0.0214 & -0.0035 \\
FE & $(0.0223)$ & $(0.0153)$ & $(0.0166)$ & $(0.0256)$ & $(0.0190)$ & $(0.0204)$ \\
Obs. & - & - & - & Yes & Yes & Yes \\
$\mathrm{R}^{2}$ (within) & 368 & 368 & 368 & 368 & 368 & 368 \\
\hline
\end{tabular}

Notes: The endogenous variable is the log of per capita revenues of bars and restaurants, bars or restaurants. Standard errors are robust for heteroscedasticity and clustered at the state (Bundesländer) level. ${ }^{*},{ }^{* *}$ and ${ }^{* * *}$ denote significance at the 10,5 , and 1 percent levels, respectively.

\section{Conclusion}

This paper investigates the impact of the German smoking ban legislation on per capita revenues of bars and restaurants. In addition to panel regression, we conducted a DD approach to analyze significant impact immediately following the new legislation, as well as on post-intervention trends. Based on our panel regression analyses, we cannot affirm a negative impact on revenues in line with existing literature. If any, our spline models indicate a positive influence of the smoking bans on revenues. Our DD results, which exploit the distinct dates of implementation in the states, providing a better control for the overall macroeconomic conditions, instead point to a significantly negative short-run impact on the revenues of bars but not restaurants. In sum, our results draw a picture of limited negative short-run impact, followed by a recovery effect. Over the course of our study period, the consumption pattern either did not change at all or reduced

Comparing the reduction in revenues in the third quarter of 2007 to that of the previous year, the statistical office finds a $9.8 \%$ reduction in states which introduced smoking bans compared to a $6.8 \%$ reduction in states without smoking-ban legislation. 
spending by smokers was compensated for by a corresponding or more than corresponding increase by non-smokers. These findings support the German - and similar - non-smoking legislations in the sense that positive externalities resulting from initiatives to reduce health care cost are likely to outweigh the risk to businesses in the hospitality sector, at least in the long run.

\section{Literature}

ADAMS, S., \& COTTI, C. D. (2007). The Effect of Smoking Bans on Bars and Restaurants: An Analysis of Changes in Employment. B.E. Journals of Economic Analysis \& Policy: Contributions to Economic Analysis \& Policy, 7(1), 1-32.

ADDA, J., BERLINSKI, S., \& MACHIN, S. (2007). Short-Run Economic Effects of the Scottish Smoking Ban. International Journal of Epidemiology, 36(1), 149-154.

AHLFELDT, G. M., \& MAENNIG, W. (2009). Arenas, Arena Architecture and the Impact on Location Desirability: The Case of "Olympic Arenas" in Berlin-Prenzlauer Berg. Urban Studies, 46(7), 1343-1362.

ALAMAR, B. C., \& GLANTZ, S. A. (2004). Smoke-Free Ordinances Increase Restaurant Profit and Value. Contemporary Economic Policy, 22(4), 520-525.

ALPERT, H. R., CARPENTER, C. M., TRAVERS, M. J., \& CONNOLlY, G. N. (2007). Environmental and Economic Evaluation of the Massachusetts Smoke-Free Workplace Law. Journal of Community Health, 32(4), 269-281.

BALTAGI, B. H. (2001). Econometric Analysis of Panel Data. New York: John Wiley.

BERTRAND, M., DUFLO, E., \& MULLAINATHAN, S. (2004). How Much Should We Trust Difference-in-Difference Estimates? The Quarterly Journal of Economics, 119(1), 249-275.

BLECHER, E. H. (2006). The Effects of the Tobacco Products Control Amendment Act of 1999 on Restaurant Revenues in South Africa: A Panel Data Approach. South African Journal of Economics, 74(1), 123-130.

BUNDESMINISTERIUM FÜR GESUNDHEIT. (2007). Freiwillige Selbstverpflichtung Der Gastronomie Zum Nichtraucherschutz Gescheitert - Rauchverbot Soll Ohne Ausnahmen Gelten. Press Release February 25, 2007.

BUNDESMINISTERIUM FÜR GESUNDHEIT UND SOZIALE SICHERUNG/DEUTSCHER HOTEL UND GASTSTÄTTENVERBAND. (2005). Nichtraucherschutz in Hotellerie Und Gastronomie. Vereinbarung Vom 1. März 2005.

COWLING, D. W., \& BOND, P. (2005). Smoke-Free Laws and Bar Revenues in California the Last Call. Health Economics, 14(12), 1273-1281.

DAI, C., DENSLOW, D., HYLAND, A., \& LOTFINIA, B. (2004). The Economic Impact of Florida's Smoke-Free Workplace Law. Gainesville: Bureau of Economic and Business Research, University of Florida.

DUNHAM, J., \& MARLOW, M. L. (2000). Smoking Laws and Their Differential Effects on Restaurants, Bars, and Taverns. Contemporary Economic Policy, 18(3), 326.

DUNHAM, J., \& MARLOW, M. L. (2003). The Economic Incidence of Smoking Laws. Applied Economics, 35(18), 1935-1942.

EDWARDS, R., THOMSON, G., WILSON, N., WAA, A., BULLEN, C., O`DEA, D., GIFFORD, H., GLOVER, M., LAUGESEN, M., \& WOODWARD, A. (2008). After the Smoke Has Cleared: Evaluation of the Impact of a New National Smoke-Free Law in New Zealand. Tobacco Control Research Paper, 2008(e2). 
EVANS, M. K. (2005). The Economic Impact of Smoking Bans in Ottawa, London, Kingston and Kitchener, Ontario [Electronic Version] from http://www.tlw.org/public/content/Documents/Smoking\%20Ban/Evans\%20Rep ort\%20Summary\%20(Canada).pdf.

FLECK, R. K., \& HANSSEN, F. A. (2008). Why Understanding Smoking Bans Is Important for Estimating Their Effects: California's Restaurant Smoking Bans and Restaurant Sales. Economic Inquiry, 46(1), 60-76.

GLANTZ, S. A., \& CHARLESWORTH, A. (1999). Tourism and Hotel Revenues before and after Passage of Smoke-Free Restaurant Ordinances. Journal of the American Medical Association, 281(20), 1911-1918.

GLANTZ, S. A., \& SMITH, L. R. A. (1994). The Effect of Ordinances Requiring Smoke-Free Restaurants on Restaurant Sales. American Journal of Public Health, 84(7), 10811085.

GLANTZ, S. A., \& SMITH, L. R. A. (1997). The Effect of Ordinances Requiring Smoke-Free Restaurants on Restaurant Sales. American Journal of Public Health, 87(10), 17291730.

GREENE, W. H. (2003). Econometric Analysis. London: Prentice-Hall.

HALVORSEN, R., \& PALMOUIST, R. (1980). The Interpretation of Dummy Variables in Semilogarithmic Equations. American Economic Review, 70(3), 474-475.

LIGHTWOOD, J., COLLINS, H., LAPSLEY, H., \& NOVOTNY, T. E. (2000). Estimating the Cost of Tobacco Use. In P. JHA \& F. CHALOUPKA (Eds.), Tobacco Control in Developing Countries. Oxford: Oxford University Press.

MARSH, L. C., \& CORMIER, D. R. (2001). Spline Regression Models. Thousand Oaks, London, New Delhi: Sage.

PAKKO, M. R. (2006). On the Economic Analysis of Smoking Bans. Regional Economic Development, 2(2).

PAKKO, M. R. (2007). The Economic Impact of Smoking Ban in Columbia, Missouri: A Preliminary Analysis of Sales Tax Data. Center for Regional Economics Occational Report, 2007-02.

PARKER, B. T., \& CHIANG, E. P. (2007). Addressing the Revenue Impact of Smoking Ordinances. Applied Economics Letters, 14(10-12), 871-875.

REDDING, S. J., \& STURM, D. M. (2008). The Costs of Remoteness: Evidence from German Division and Reunification. American Economic Review, 98(5), 1766-1797.

SCIACCA, J. P., \& RATLIFF, M. I. (1998). Prohibiting Smoking in Restaurants: Effects on Restaurant Sales American journal of health promotion, 12(3), 176-184.

SCOLLO, M., \& LAL, A. (2008). Summary of Studies Assessing the Economic Impact of Smoke-Free Policies in the Hospitality Industry. VicHealth Centre for Tobacco Control.

STATISTISCHES BUNDESAMT. (2008a). Qualitätsbericht Monatserhebung im Gastgewerbe, Febuary 2008.

STATISTISCHES BUNDESAMT. (2008b). Rauchverbote und Umsätze Im Gaststättengewerbe, Press Release June 6, 2008.

STOLZENBERG, L., \& D'ALESSIO, S. J. (2007). Is Nonsmoking Dangerous to the Health of Restaurants? The Effect of California's Indoor Smoking Ban on Restaurant Revenues. Eval Rev, 31(1), 75-92.

THOMPSON, E., HAHN, E. J., BLOMOUIST, G., GAREN, J., MULLINEAUX, D., OGUNRO, N., \& RAYENS, M. K. (2008). Smoke-Free Laws and Employee Turnover. Contemporary Economic Policy, 26(3), 351-359. 
Table A1: Smoking bans in German states

\begin{tabular}{|c|c|c|c|c|c|c|c|}
\hline \multirow[t]{2}{*}{ State } & \multirow[t]{2}{*}{ Legal basis of smoking ban } & \multicolumn{5}{|c|}{ Regulation for hospitality industry prior to BVerfG decision } & \multirow[t]{2}{*}{$\begin{array}{l}\text { Regulation after BVerfG } \\
\text { decision }\end{array}$} \\
\hline & & Entry into effect & $\begin{array}{l}\text { Smoking room } \\
\text { allowed }\end{array}$ & $\begin{array}{l}\text { Smoking ban in } \\
\text { micro-enterprises }\end{array}$ & $\begin{array}{l}\text { Smoking ban in party } \\
\text { tents }\end{array}$ & $\begin{array}{l}\text { Smoking ban in } \\
\text { discothèques }\end{array}$ & \\
\hline $\begin{array}{l}\text { Baden- } \\
\text { Württem-berg }\end{array}$ & $\begin{array}{l}\text { State Non-Smokers Protection Act } \\
\text { (LNRSchG) dated 25.7.2007 }\end{array}$ & 1.8 .2007 & + & + & - & $\begin{array}{l}+ \text { (smoking room not } \\
\text { allowed })\end{array}$ & $\begin{array}{l}\text { Exceptions under condi- } \\
\text { tions of BVerfG }\end{array}$ \\
\hline Bavaria & $\begin{array}{l}\text { Health Protection Act (GSG) dated } \\
20.12 .2007\end{array}$ & 1.1 .2008 & - & + & $\begin{array}{l}+ \text { (but not allowed } \\
\text { from 22.7.2008 to } \\
31.12 .2008 \text { ) }\end{array}$ & $\begin{array}{l}+ \text { (smoking room not } \\
\text { allowed) }\end{array}$ & No changes \\
\hline Berlin & $\begin{array}{l}\text { Protection from the Dangers of Pas- } \\
\text { sive Smoking in Public Act (Non- } \\
\text { Smokers Protection Act - NRSG) dated } \\
8.11 .2007\end{array}$ & $\cdot .1 .2008$ & + & + & $\begin{array}{l}+ \text { (if restaurant under } \\
\text { B7 s. } 1 \text { GastG) }\end{array}$ & $\begin{array}{l}+ \text { (smoking room not } \\
\text { allowed) }\end{array}$ & $\begin{array}{l}\text { Exceptions under condi- } \\
\text { tions of BVerfG }\end{array}$ \\
\hline Branden-burg & $\begin{array}{l}\text { Protection from the Dangers of Pas- } \\
\text { sive Smoking in Public Act (Non- } \\
\text { Smokers Protection Act of Branden- } \\
\text { burg - BgbNiRSchG) dated } 18.12 .2007\end{array}$ & 1.1 .2008 & + & + & $\begin{array}{l}+ \text { (if restaurant under } \\
\text { s. } 1 \text { GastG) }\end{array}$ & $\begin{array}{l}+ \text { (smoking room not } \\
\text { allowed) }\end{array}$ & $\begin{array}{l}\text { Exceptions under condi- } \\
\text { tions of BVerfG }\end{array}$ \\
\hline Bremen & $\begin{array}{l}\text { Non-Smokers Protection Act of Bre- } \\
\text { men (Brem-NiSchG) dated 18.12.2007 }\end{array}$ & 1.1 .2008 & + & + & $\begin{array}{l}\text { - (for certain fairs } \\
\text { and festivals) }\end{array}$ & $\begin{array}{l}+ \text { (Smoking room } \\
\text { allowed) }\end{array}$ & $\begin{array}{l}\text { Exceptions under condi- } \\
\text { tions of BVerfG }\end{array}$ \\
\hline Hamburg & $\begin{array}{l}\text { Protection from the Dangers of Pas- } \\
\text { sive Smoking in Public Act (Non- } \\
\text { Smokers Protection Act of Hamburg- } \\
\text { HmbPSchG) dated 11.7.2007 }\end{array}$ & 1.1 .2008 & + & + & $\begin{array}{l}\text { - (events limited in } \\
\text { time and space as } \\
\text { well as club houses) }\end{array}$ & $\begin{array}{l}+ \text { (Smoking room } \\
\text { allowed) }\end{array}$ & $\begin{array}{l}\text { Exceptions under condi- } \\
\text { tions of BVerfG }\end{array}$ \\
\hline Hesse & $\begin{array}{l}\text { Protection from the Dangers of Pas- } \\
\text { sive Smoking Act (Non-Smokers Pro- } \\
\text { tection Act of Hesse - HessNRSG) } \\
\text { dated 6.9.2007 }\end{array}$ & 1.10 .2007 & + & + & $\begin{array}{l}\text { - (for temporary } \\
\text { operations) }\end{array}$ & $\begin{array}{l}+ \text { (Smoking room } \\
\text { allowed) }\end{array}$ & $\begin{array}{l}\text { Exceptions under condi- } \\
\text { tions of BVerfG }\end{array}$ \\
\hline $\begin{array}{l}\text { Mecklenburg- } \\
\text { Western Pom- } \\
\text { erania }\end{array}$ & $\begin{array}{l}\text { Non-Smokers Protection Act of Meck- } \\
\text { lenburg-Western Pomerania } \\
\text { (NichtRSchutzG M-P) dated 12.7.2007 }\end{array}$ & 1.1 .2008 & + & + & $\begin{array}{l}+ \text { (if restaurant under } \\
\text { s. } 1 \text { GastG) }\end{array}$ & $\begin{array}{l}+ \text { (Smoking room } \\
\text { allowed) }\end{array}$ & $\begin{array}{l}\text { Exceptions under condi- } \\
\text { tions of BVerfG }\end{array}$ \\
\hline Lower Saxony & $\begin{array}{l}\text { Non-Smokers Protection Act of Lower } \\
\text { Saxony (Nds.NiSG) dated 12.7.2007 }\end{array}$ & 1.8.2007 & + & + & + & $\begin{array}{l}+ \text { (Smoking room } \\
\text { allowed) }\end{array}$ & $\begin{array}{l}\text { Exceptions under condi- } \\
\text { tions of BVerfG }\end{array}$ \\
\hline $\begin{array}{l}\text { North-Rhine- } \\
\text { Westphalia }\end{array}$ & $\begin{array}{l}\text { Protection of Non-Smokers Act of } \\
\text { North-Rhine-Westphalia (Non- } \\
\text { Smokers Protection Act NR W - NiSchG } \\
\text { NRW) dated 20.12.2007 }\end{array}$ & 1.2 .2008 & + & + & + & $\begin{array}{l}+ \text { (Smoking room } \\
\text { allowed) }\end{array}$ & $\begin{array}{l}\text { Exceptions under condi- } \\
\text { tions of BVerfG }\end{array}$ \\
\hline $\begin{array}{l}\text { Rhineland- } \\
\text { Palatinate }\end{array}$ & $\begin{array}{l}\text { Non-Smokers Protection Act of Rhine- } \\
\text { land-Palatinate (NRauchSchG RP) } \\
\text { dated 5.10.2007 }\end{array}$ & 15.2 .2008 & + & - & $\begin{array}{l}\text { - (for temporary } \\
\text { operations) }\end{array}$ & $\begin{array}{l}+ \text { (Smoking room } \\
\text { allowed) }\end{array}$ & No change \\
\hline
\end{tabular}




\begin{tabular}{|c|c|c|c|c|c|c|c|}
\hline \multirow[t]{2}{*}{ State } & \multirow[t]{2}{*}{ Legal basis of smoking ban } & \multicolumn{5}{|c|}{ Regulation for hospitality industry prior to BVerfG decision } & \multirow[t]{2}{*}{$\begin{array}{l}\text { Regulation after BVerfG } \\
\text { decision }\end{array}$} \\
\hline & & Entry into effect & $\begin{array}{l}\text { Smoking room } \\
\text { allowed }\end{array}$ & $\begin{array}{l}\text { Smoking ban in } \\
\text { micro-enterprises }\end{array}$ & $\begin{array}{l}\text { Smoking ban in party } \\
\text { tents }\end{array}$ & $\begin{array}{l}\text { Smoking ban in } \\
\text { discothèques }\end{array}$ & \\
\hline Saarland & $\begin{array}{l}\text { Protection from the Dangers of Pas- } \\
\text { sive Smoking Act (Non-Smokers Pro- } \\
\text { tection Act - NrauchSchG SL) dated } \\
\text { 21.11.2007 }\end{array}$ & 15.2 .2008 & + & $\begin{array}{l}\text { - (if owner- } \\
\text { operated restau- } \\
\text { rant without staff) }\end{array}$ & + & $\begin{array}{l}+ \text { (Smoking room } \\
\text { allowed) }\end{array}$ & No change \\
\hline Saxony & $\begin{array}{l}\text { Protection of Non-Smokers in the Free } \\
\text { State of Saxony Act (Non-Smokers } \\
\text { Protection Act of Saxony - SächsNSG) } \\
\text { dated 26.10.2007. }\end{array}$ & 1.2 .2008 & + & $\begin{array}{l}- \text { - (if owner- } \\
\text { operated restau- } \\
\text { rant without staff; } \\
\text { only since } \\
1.3 .2008 \\
\end{array}$ & $\begin{array}{l}\text { + (if restaurant under } \\
\text { s. } 1 \text { GastG) }\end{array}$ & $\begin{array}{l}+ \text { (smoking room not } \\
\text { allowed) }\end{array}$ & $\begin{array}{l}\text { Exceptions under condi- } \\
\text { tions of BVerfG }\end{array}$ \\
\hline Saxony-Anhalt & $\begin{array}{l}\text { Protection of Non-Smokers Act in the } \\
\text { State of Saxony-Anhalt (Non-Smokers } \\
\text { Protection Act) dated 19.12.2007 }\end{array}$ & 1.1 .2008 & + & + & $\begin{array}{l}\text { + (if restaurant under } \\
\text { s. } 1 \text { GastG) }\end{array}$ & $\begin{array}{l}+ \text { (smoking room not } \\
\text { allowed) }\end{array}$ & $\begin{array}{l}\text { Exceptions under condi- } \\
\text { tions of BVerfG from } \\
22.10 .2008\end{array}$ \\
\hline $\begin{array}{l}\text { Schleswig- } \\
\text { Holstein }\end{array}$ & $\begin{array}{l}\text { Protection from the Dangers of Pas- } \\
\text { sive Smoking Act dated 21.11.2007 }\end{array}$ & 1.1 .2008 & + & + & $\begin{array}{l}\text { - (for temporary } \\
\text { operations) }\end{array}$ & $\begin{array}{l}+ \text { (Smoking room } \\
\text { allowed) }\end{array}$ & $\begin{array}{l}\text { Exceptions under condi- } \\
\text { tions of BVerfG }\end{array}$ \\
\hline Thuringia & $\begin{array}{l}\text { Protection from the Dangers of Pas- } \\
\text { sive Smoking Act of Thuringia (Non- } \\
\text { Smokers Protection Act of Thuringia - } \\
\text { ThürNRSchutzG) dated 20.12.2007 }\end{array}$ & 1.7 .2008 & + & + & $\begin{array}{l}\text { + (if restaurant under } \\
\text { s. } 1 \text { GastG) }\end{array}$ & $\begin{array}{l}+(\text { Smoking room } \\
\text { allowed) }\end{array}$ & $\begin{array}{l}\text { Exceptions under condi- } \\
\text { tions of BVerfG }\end{array}$ \\
\hline
\end{tabular}




\section{Hamburg Contemporary Economic Discussions}

(Download: http://www.uni-hamburg.de/economicpolicy/discussions.html)

01/2005 FEDDERSEN, A. / MAENNIG, W.: Trends in Competitive Balance: Is there Evidence for Growing Imbalance in Professional Sport Leagues?, January 2005.

02/2005 SIEVERS, T.: Information-driven Clustering - An Alternative to the Knowledge Spillover Story, February 2005.

03/2005 SIEVERS, T.: A Vector-based Approach to Modeling Knowledge in Economics, February 2005.

04/2005 BUETTNER, N. / MAENNIG, W. / MENSSEN, M.: Zur Ableitung einfacher Multiplikatoren für die Planung von Infrastrukturkosten anhand der Aufwendungen für Sportstätten - eine Untersuchung anhand der Fußball-WM 2006, May 2005.

01/2006 FEDDERSEN, A.: Economic Consequences of the UEFA Champions League for National Championships - The Case of Germany, May 2006.

02/2006 FEDDERSEN, A.: Measuring Between-season Competitive Balance with Markov Chains, July 2006.

03/2006 FEDDERSEN, A. / VÖPEL, H.: Staatliche Hilfen für Profifußballclubs in finanziellen Notlagen? - Die Kommunen im Konflikt zwischen Imageeffekten und Moral-Hazard-Problemen, September 2006.

04/2006 MAENNIG, W. / SCHWARTHOFF, F.: Stadium Architecture and Regional Economic Development: International Experience and the Plans of Durban, October 2006. 


\section{Hamburg Contemporary Economic Discussions}

(Download: http://www.uni-hamburg.de/economicpolicy/discussions.html)

01

02

03

04

05

06

07

08

O9

10

11

12

13

AHLFELDT, G. / MAENNIG, W.: The Role of Architecture on Urban Revitalization: The Case of "Olympic Arenas" in Berlin-Prenzlauer Berg, 2007.

FEDDERSEN, A. / MAENNIG, W. / ZIMMERMANN, P.: How to Win the Olympic Games - The Empirics of Key Success Factors of Olympic Bids, 2007.

AHLFELDT, G. / MAENNIG, W.: The Impact of Sports Arenas on Land Values: Evidence from Berlin, 2007.

DU PLESSIS, S. / MAENNIG, W.: World Cup 2010: South African Economic Perspectives and Policy Challenges Informed by the Experience of Germany 2006, 2007.

HEYNE, M. / MAENNIG, W. / SUESSMUTH, B.: Mega-sporting Events as Experience Goods, 2007.

DUST, L. I MAENNIG, W.: Shrinking and Growing Metropolitan Areas - Asymmetric Real Estate Price Reactions? The Case of German Single-family Houses, 2007.

JASMAND, S. / MAENNIG, W.: Regional Income and Employment Effects of the 1972 Munich Olympic Summer Games, 2007.

HAGN, F. / MAENNIG W.: Labour Market Effects of the 2006 Soccer World Cup in Germany, 2007.

HAGN, F. / MAENNIG, W.: Employment Effects of the World Cup 1974 in Germany.

MAENNIG, W.: One Year Later: A Re-appraisal of the Economics of the 2006 Soccer World Cup, 2007.

AHLFELDT, G., MAENNIG, W.: Assessing External Effects of City Airports: Land Values in Berlin, 2007.

AHLFELDT, G.: If Alonso was Right: Accessibility as Determinant for Attractiveness of Urban Location, 2007.

AHLFELDT, G.: A New Central Station for a Unified City: Predicting Impact on Property Prices for Urban Railway Network Extension, 2007. 


\section{Hamburg Contemporary Economic Discussions}

(Download: http://www.uni-hamburg.de/economicpolicy/discussions.html)

FEDDERSEN, A. / MAENNIG, W.: Arenas vs. Multifunctional Stadia Which Do Spectators Prefer?, 2007.

AHLFELDT, G. / FEDDERSEN, A.: Geography of a Sports Metropolis, 2007.

FEDDERSEN, A. / GRÖTZINGER, A. / MAENNIG, W.: New Stadia and Regional Economic Development - Evidence from FIFA World Cup 2006 Stadia, 2008.

AHLFELDT, G. / MAENNIG, W.: Monumental Protection: Internal and External Price Effects, 2008.

MAENNIG, W. / PORSCHE, M.: The Feel-good Effect at Mega Sport Events - Recommendations for Public and Private Administration Informed by the Experience of the FIFA World Cup 2006, 2008.

AHLFELDT, G.: The Train has Left the Station: Real Estate Price Effects of Mainline Realignment in Berlin, 2008.

MAENNIG, W. / WELLBROCK, C.-M.: Sozio-ökonomische Schätzungen Olympischer Medaillengewinne: Analyse-, Prognose- und Benchmarkmöglichkeiten, 2008.

MAENNIG, W. / ALLERMS, S.: South Africa 2010: Economic Scope and Limits, 2008.

AHLFELDT, G. / FEDDERSEN, A.: Determinants of Spatial Weights in Spatial Wage Equations: A Sensitivity Analysis, 2008.

AHLFELDT, G. / WENDLAND, N.: Fifty Years of Urban Accessibility: The Impact of Urban Railway Network on the Land Gradient in Industrializing Berlin, 2008.

AHLFELDT, G. / FRANKE, B. / MAENNIG, W.: Terrorism and the Regional and Religious Risk Perception of Foreigners: The Case of German Tourists, 2009.

FEDDERSEN, A. / MAENNIG, W.: Wage and Employment Effects of the Olympic Games in Atlanta 1996 Reconsidered, 2009.

AHLFELDT, G. I MAENNIG, W.: Impact of Non-Smoking Ordinances on Hospitality Revenues: The Case of Germany. 
